\title{
Traditional budgeting during financial crisis
}

\section{El presupuesto tradicional en la crisis económica}

\author{
MARIE-ANne Lorain ${ }^{1}$ \\ Aurora García Domonte ${ }^{2}$ \\ Francisco Sastre Peláez ${ }^{2}$ \\ ESCP Europe (España) \\ Universidad Pontificia Comillas - ICADE (España)
}

Recibido el 7 de julio de 2014, aceptado el 14 de noviembre de 2014

$\mathrm{N}^{\circ}$ de clasificación JEL: M21, M49

DOI: $10.5295 / \mathrm{cdg} .140480 \mathrm{ag}$

\begin{abstract}
:
This study examines the evolution of budgeting practices in the extremely difficult Spanish economic environment. In order to analyse if companies are still maintaining their budgeting process and if, right now, they are facing more difficulties in forecasting accurate indicators, two similar web surveys were addressed over two periods of time, firstly in 2008 at the beginning of the financial crisis, and secondly in 2013 after five years of a downward trend. In addition, in-depth interviews were conducted to investigate how companies brought more flexibility to their budgeting process in order to cope with environmental uncertainty.

The survey indicates that $97 \%$ of respondents are still using a traditional budgeting process being this result similar to the one found in 2008. However, 2013 showed that the reliance on forecasted information is being increasingly questioned. Furthermore the study revealed that the respondents are bringing more flexibility to their processes, being able to modify the objectives once the budget is approved and to obtain new resources outside the budgeting process.

This paper contributes to revealing information about difficulties in setting reliable objectives in a turbulent environment and provides data about the evolution of budgeting practices over five years during an austere economic crisis.
\end{abstract}

\section{Keywords:}

Traditional budgeting, planning, uncertainty, management control.

\section{Resumen:}

Este estudio examina la evolución de la gestión presupuestaria en el extremadamente difícil entorno económico español. A fin de analizar si las empresas aún continúan utilizando los presupuestos y si se están enfrentando a mayores dificultades para lograr unas predicciones fiables, se han realizado dos encuestas similares en

\footnotetext{
${ }^{1}$ ESCP Europe, Campus Madrid, C/ Arroyofresno 1, 28035 Madrid (España).mlorain@escpeurope.eu

2 Departamento de Gestión Financiera, Universidad Pontificia Comillas - ICADE, C/ Alberto Aguilera 23, 28015 Madrid (España).agdomonte@comillas.edu; fsastre@comillas.edu
} 
fechas distintas, la primera en 2008, al inicio de la crisis financiera, y la segunda en 2013, después de cinco años de tendencia bajista. Los resultados obtenidos con este trabajo de campo se han complementado con diversas entrevistas en profundidad, a fin de investigar cómo las organizaciones incorporan mayor flexibilidad en sus procesos presupuestarios para hacer frente a la incertidumbre del entorno.

Los resultados muestran que hoy el $97 \%$ de las empresas encuestadas utilizan los presupuestos tradicionales en su gestión (dato similar al obtenido en 2008). Sin embargo, en 2013, la confianza en la información proporcionada se cuestiona cada vez más. Se ha detectado que estas empresas crean nuevas formas para aportar mayor flexibilidad a sus procesos.

Este estudio contribuye a proporcionar mayor información sobre las dificultades para establecer objetivos realistas en entornos turbulentos y proporciona información sobre la evolución de las prácticas presupuestarias a lo largo de cinco años de profunda crisis económica.

\section{Palabras clave:}

Presupuesto tradicional, planificación, incertidumbre, control de gestión. 


\section{INTRODUCTION}

The turbulent economic environment has justified the introduction of budgetary controls in companies. As a matter of fact, traditional corporate budgets were developed and implemented throughout the Great Depression, as a means to help companies overcome a critical situation characterized by a drop in domestic consumption, deflation and profit margin reduction (Berland et al. 2009). They succeeded, and only a few years later they became the most important tool for management control (Fernandez and Rodriguez 2011). In fact, since then, the terms "management control" and "budgetary control" have been synonymous.

Nevertheless, this leading position does not mean that the budgetary technique has not been subject to much criticism, such as an inability to operate properly in highly uncertain situations, high costs, little value, fast obsolescence of information, etc. (Van der Stede 2000; Neely et al. 2001; Hope and Fraser 2003; Covaleski et al. 2003; Otley 2006; Frow et al. 2010; Ekholm and Wallin 2011). Some of the main failures in its conceptual structure as well as in its practical application to the real world have been highlighted as the result of a long process of critical analysis. (Hope and Fraser 1997, 2000, 2003; Jensen 2001). In the middle of the 20th Century, the complaints stemmed from the methodology and poor results produced by the budgetary policies. Thirty years later, however, critiques were aimed at the very core of the planning technique, i.e. at its foundations and basic philosophy. However, current research suggests that this kind of criticism has its counterargument. The traditional annual budget may be used as a buffer against uncertainty, allowing a set of systematic - rather than erratic - reactions against change. Furthermore, budget and other management control devices play a critical role in creating competitive pressure in the firm, boosting innovation and adaptation (Simons 1995). These conclusions are also confirmed by prior studies carried out by various authors in different environments (Horngren et al. 1996; Libby and Lindsay 2010; Ekholm and Wallin 2011).

The situation could currently be described as paradoxical. A large number of empirical investigations in different countries and environments reveal that more than $90 \%$ of the companies consider the budget as an indispensable tool for corporate management (Apanaschik 2007; Arwidi and Jönsson 2009; Libby and Lindsay 2010; Doche 2012). On the other hand, however, the same companies complain about the budget's serious drawbacks and agree that it needs to undergo a thorough reform (Hope and Fraser 1997, 2000, 2003; Frow et al. 2010).

Companies consider the budget as a "very useful" tool due to its functions within the organization and in relation to the expected outcomes generated from its use. The study of the literature shows that the budget could be used as a supporting device in many ways and in different management areas (see Table 1).

Table 1

\section{Traditional budget functions}

\begin{tabular}{l|c}
\hline Function & Reference \\
\hline Planning & $\begin{array}{c}\text { Baudet 1941; Hopwood 1974; Barrett and Fraser 1977; Hofstede 1977; Otley } \\
\text { 1977; Samuelson 1986; Lyne 1988; Bunce et al. 1995; Bouquin 2001. }\end{array}$ \\
\hline $\begin{array}{l}\text { Budget Mana- } \\
\text { gement }\end{array}$ & $\begin{array}{c}\text { Baudet 1941; Hofstede 1977; Otley, 1977; Samuelson 1986; Lyne 1988; Bunce } \\
\text { et al. 1995. }\end{array}$ \\
\hline
\end{tabular}




\begin{tabular}{l|c}
\hline Evaluation & $\begin{array}{c}\text { Baudet 1941; Barrett and Fraser 1977; Otley 1977; Samuelson 1986; Lyne 1988; } \\
\text { Bunce et al. 1995. }\end{array}$ \\
\hline Motivation & Hopwood 1974; Barrett and Fraser 1977; Otley 1977; Samuelson 1986; Lyne \\
& 1988; Bouquin 2001. \\
\hline Commitment & Samuelson 1986. \\
\hline Delegation & Hopwood 1974; Bouquin 2001. \\
\hline Coordination & Baudet 1941; Hopwood 1974; Barrett and Fraser 1977; Samuelson 1986; Lyne \\
\hline $\begin{array}{l}\text { Communica- } \\
\text { tion }\end{array}$ & Otley 1977; Lyne 1988; Bunce et al. 1995; Bouquin 2001. \\
\hline
\end{tabular}

Source: adapted from Berland (1999, p.7).

One of the main benefits of budgeting comes from the position of the process located at the center of the management control system. In order to properly manage their activities, anticipate decisions, assess future results, and ensure a sustainable growth, managers need a clear vision of what is currently happening. The budgetary process, thanks to the planning function, puts the present and the future into perspective.

The summary of the literature on budgeting process, presented on Table 1, shows the main functions assigned to business planning. These functions fulfill the following objectives: management of financial equilibrium, organizational adjustment, control and regulation of performance, managers' behavior orientation and commitment.

Management of financial equilibrium is obtained through the planning function. The budget helps to define and delegate common objectives within the entire organization, making these converge towards the overall company's strategic goal, which contributes to organizational adjustment (delegation function).

Budget management, together with the evaluation function, provides senior management with an analysis tool that allows performance measurement and results regulation. The preset objectives guide the actions of operating managers towards their area's key variables. At the same time, the monitoring of financial indicators provides useful information to manage these variables.

Manager's behavior orientation and commitment (motivation and commitment functions) are achieved through the setting of objectives in collaboration with managers, which encourages their motivation (Hofstede 1977). Managers' involvement promotes the exchange of information (communication function), which makes budgetary objectives more reliable and reinforce cohesion within the organization (coordination function).

Budgeting is a key element of the management control system because it is one of the processes more deeply rooted in the organizational structures and is the only system that covers all the organizational areas of the company (Otley 2006).

In the research, we have highlighted three basic functions among those mentioned in Table 1. These three main functions: planning, budget management and motivation are of general interest among the companies analyzed. Other functions such as delegation, coor- 
dination and communication have been discarded in this study, for being less linked to the uncertainty of the environment.

\section{- Planning function}

Probably the most important task assigned to budgeting is to provide reliable information in order to anticipate the future. This would allow companies to carry out an effective planning process, i.e. an organized and structured way to reach their strategic goals. However, a portion of the doctrine claims that in a world characterized by a high level of uncertainty, the traditional budget cannot provide companies with faithful estimations (Hope and Fraser 1997, 2000, 2003; Jensen 2001). Besides, in a fast-moving economic and social environment, budgetary information would certainly become quickly outdated. Planning is one of the most criticized functions in a changing economic environment and it seems essential to us to analyze it in this investigation.

\section{- $\quad$ Budget management function}

Business planning provides key reference standards for measuring the efficiency of the company's performance. Budget is subject to examination and analysis by shareholders, financial analysts or any other stakeholder that has interests in the company. Budget management allows, through the analysis of variances between forecasted and actual figures, to understand the progress of the business. Amat et al. (2002) highlight the importance of the budget process within the company: "the double slope of anticipation and analysis of what happened makes budgetary control an essential tool for leading companies in hostile and changing environments". In this study, great interest was directed towards the analysis of the budget management process and its possible evolution in an uncertain environment.

\section{- Motivation function}

Budgeting, through the motivation function, directs the managers' behavior. In general, the budgetary objectives have been negotiated with the managers and their hierarchy and can be seen as a contract or a formal obligation to produce results. However, in times of crisis and changes in the economic environment, the objectives initially negotiated in the budget may be difficult to achieve. Then, managers could be discouraged since there is a correlation between the feasibility of the objective and the degree of motivation (Merchant 1998). Therefore, the motivation function is an important point in the budget control system and even more in shifting environments.

The aim of this article is, then, to examine whether companies continue to consider budgeting as a key element for management control, and if the process still covers the basic functions mentioned above. Furthermore, through anonymous surveys and case studies, the objective of the present study is to analyze the evolution of budgeting practices in the austere economic environment Spanish companies are currently facing.

The first section of this paper deals with the Spanish economic context in which the present study is framed, the investigation objectives and the research method employed. In the second section, the results of the web-based survey and the qualitative interviews are reported and analyzed. The last section shows a summary of the investigation findings and presents the main conclusions. 


\section{INVESTIGATION FRAMEWORK}

In times of the economic crisis and low growth, the environment becomes more uncertain and companies are directly affected by this situation. Today, weakness in global economic activity are influencing - to a greater or lesser extent - the more developed countries and emerging countries.

The international recession in which Europe is immersed since August 2008 has been particularly hard-hitting on the Spanish economy. This phenomenon can be observed by analyzing the major indicators used to reflect the economic situation of a country, such as the economic growth, inflation rate, external and public deficit, and the unemployment rate.

Figure 1

Main macroeconomic indicators of the Spanish economy 2000-2012

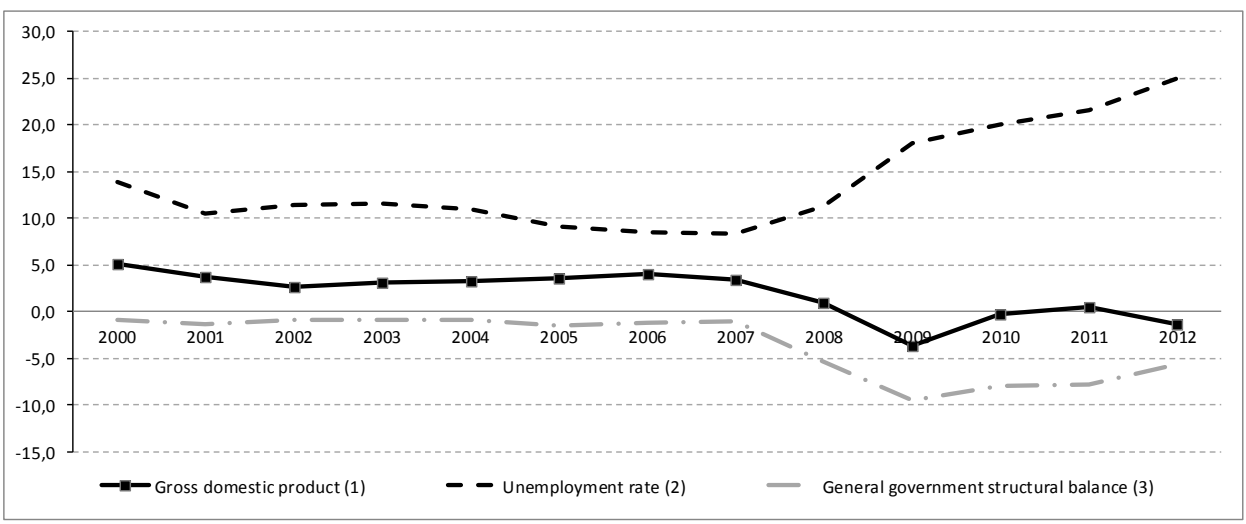

1. Gross domestic product $(G D P)$ : Annual percentages of constant price GDP are from year-to-year changes. Expenditure-based GDP is total final expenditures at purchasers prices (including the F.O.B. value of exports of goods and services), less the F.O.B. value of imports of goods and services.

2. Unemployment rate (UR): The unemployment rate gives the number of unemployed persons as a percentage of the labor force (the total number of people employed plus unemployed).

3. General government structural balance (or Public Deficit PD): The structural budget balance refers to the general government cyclically adjusted balance adjusted for nonstructural elements beyond the economic cycle, as a percentage of potential GDP.

Source: Own elaboration based on International Monetary Fund 2013.

As shown in Figure 1, during the time preceding 2007, the Spanish economic indicators were quite stable. The turning point was recorded in 2008 when the indicators began to show negative data. 


\section{Objectives of the investigation}

This linear study looks at the way annual budgeting is carried out in a sample of Spanish companies. The investigation deals with two main questions:

- What is the evolution of budgeting practices in the austere Spanish economic environment, between 2008 and 2013, and is the planning process still fulfilling its basic functions?

- Are companies bringing more adaptability to their budgeting process in order to cope with environmental uncertainty? If so, what are the main mechanisms that are implemented?

\subsection{Web-based survey}

To address the first research question, two similar web-based surveys were sent over two periods of time, the first one in 2008 at the beginning of the financial crisis, and the second one in 2013 after four years of a downward trend. The survey method is summarized in Table 2.

Table 2

\section{Web-based survey features}

\begin{tabular}{c|c|c}
\hline & Questionnaire 2008 & Questionnaire 2013 \\
\hline Respondents & 45 & 41 \\
\hline Survey method & \multicolumn{2}{|c}{ Web-based survey } \\
\hline Running period & December 2008 to January 2009 & February to March 2013 \\
\hline Companies activity field & \multicolumn{2}{|c}{ Companies operating in an uncertain environment } \\
\hline \multirow{2}{*}{ Objectives } & \multicolumn{2}{|c}{ Investigate: } \\
& - Budgeting process and business planning functions. \\
& - Level of difficulty to elaborate reliable financial forecasts \\
& - Budget adaptability in changing environments \\
\hline
\end{tabular}

Source: Own elaboration.

The method chosen to select the sample is an "Optional Non-probabilistic sampling method" (Santesmases Mestres 2009). The sample was drawn from the 2008 "Who is who" directory of "Actualidad Económica", a Spanish weekly financial magazine. To be included in the sample, individuals must belong to a company operating in an uncertain environment. To be defined as such, the environment must include five external components: customers, competitors, suppliers, regulatory groups and technological requirements of an industry that may undergo changes and discontinuities (Duncan 1972). Markets in which technology standards are changing, competitors are continuously entering and exiting, and customers are constantly changing their preferences can be considered as belonging to a highly uncertain environment (Courtney 2008). 
A turbulent environment was defined as an economic sector where changes and unpredictable discontinuities occur frequently. For the Spanish market it was taken into account changes in external factors such as political and legal regulations (privatization, deregulation), economic factors, technology evolution, and socio-cultural factors. This led to the selection of several economic sectors such as automobiles, distribution, energy, real estate, internet, pharmaceuticals and services (Lorain 2010).

This selection resulted in a final sample of 395 organizations that has been used for both surveys (2008 and 2013). In addition, targeted respondents were selected among those holding the position of Chief Executive Officer (CEO), Chief Financial Officer (CFO), Business Controller, Director of Planning, and Budgeting, and Accounting Manager. The link to the questionnaire was e-mailed to these 395 companies. The survey was anonymous and took approximately 10 to 15 minutes to be completed.

The questionnaire was composed of 23 questions (see Appendix), which were designed taking into account the most recent and relevant surveys that have been published in this field of investigation (Neely et al. 2001; Hunt 2006, Apanaschick 2007; Arwidi and Jönsson 2009; Libby and Lindsay 2010). Most of the items are closed questions in order to obtain definitive and concise answers. Only a few questions allowed open answers.

A total of 45 surveys in 2008, and 41 questionnaires in 2013, were submitted through the web-based system. This represents a response rate of $11.4 \%$ in 2008 and $10.4 \%$ in 2013 . Descriptive statistics for respondents of both surveys are shown in Table 3.

Table 3

Study features - descriptive statistics for survey respondents

\begin{tabular}{|l|c|c|c|c|}
\cline { 2 - 5 } \multicolumn{1}{c|}{} & \multicolumn{2}{c|}{$\mathbf{2 0 0 8}$} & \multicolumn{2}{c|}{$\mathbf{2 0 1 3}$} \\
\cline { 2 - 5 } \multicolumn{1}{c|}{} & Number & frequency & Number & frequency \\
\hline Employees & & & & \\
Less than 500 people & 16 & $35,6 \%$ & 19 & $46,3 \%$ \\
More than 500 people & 29 & $64,4 \%$ & 22 & $53,7 \%$ \\
\hline Divisional revenues & 10 & $22,2 \%$ & 6 & $14,6 \%$ \\
Less than €10 million & 18 & $40,0 \%$ & 24 & $58,5 \%$ \\
From $€ 10-500$ million & 17 & $37,8 \%$ & 11 & $26,8 \%$ \\
More than €500 million & 19 & $42,2 \%$ & 11 & $26,8 \%$ \\
\hline Corporate structure & 26 & $57,8 \%$ & 30 & $73,2 \%$ \\
Stand-alone unit & & & & \\
Division of a larger organization & 27 & $60,0 \%$ & 26 & $63,4 \%$ \\
\hline Economic sector & 18 & $40,0 \%$ & 15 & $36,6 \%$ \\
Uncertain & & & & \\
Certain & 22 & $48,9 \%$ & 24 & $58,5 \%$ \\
\hline Job titles & 19 & $42,2 \%$ & 13 & $31,7 \%$ \\
CEO /CFO & 4 & $8,9 \%$ & 4 & $9,8 \%$ \\
Business controller & & & & \\
Accounting manager and other & & & & \\
\hline
\end{tabular}

Source: Own elaboration. 


\subsection{Qualitative interviews}

In order to analyze the second research question related to the adaptations made by the companies to their budgeting process, five semi-structured interviews were conducted. The main interviewee features are presented in Table 4.

Table 4

Study features for qualitative interviews

\begin{tabular}{|c|c|}
\hline & Interviews 2013 \\
\hline Respondents & 5 \\
\hline Survey method & Semi-structured interviews \\
\hline $\begin{array}{l}\text { Data analysis methodo- } \\
\text { logy }\end{array}$ & Analysis of interviews in light of practice and theory literature \\
\hline Running period & March to May 2013 \\
\hline Companies activity field & $\begin{array}{l}\text { Companies operating in a very stable or very uncertain environ- } \\
\text { ments }\end{array}$ \\
\hline Objectives & $\begin{array}{c}\text { Investigate: } \\
\text { - budgeting process, } \\
\text { - methods used to bring more flexibility in times of uncertainty. }\end{array}$ \\
\hline
\end{tabular}

Source: Own elaboration.

The interviews were addressed to Chief Financial Officers of companies selected from the initial survey sample. The group was homogeneous in terms of nature and level of responsibility in order to rely on the consistency of the information obtained.

The number of studied companies is limited. However, in the area of management control case studies are usually small sample studies; the purpose is not to publish statistics but to extend theories that explain the observations made (Ryan et al. 2004).

\section{EMPIRICAL RESULTS}

\subsection{Web-based survey}

The results of the survey allow us to respond to the first research question: what is the evolution of budgeting practices in the austere Spanish economic environment, between 2008 and 2013?

Table 5 shows the relationship between the survey questions (see Appendix) and the results obtained with the studied functions. 
86Table 5

Relationship between budget functions, their description and the survey questions

\begin{tabular}{c|c|c}
\hline FUNCTION & DESCRIPTION & QUESTIONS \\
\hline Planning & Budgeting process and its formalization level & $1,6,7,8$ \\
\cline { 2 - 3 } & Budgeting process improvement & $16,17,18$ \\
\cline { 2 - 3 } & Difficulty to forecast & $2,3,4,5$ \\
\hline $\begin{array}{c}\text { Budget manage- } \\
\text { ment }\end{array}$ & Variance analysis and periodicity of budget reviews & $9,10,11,12,15$ \\
\cline { 2 - 3 } & Budget flexibility and adaptability & $13 \mathrm{y} 14$ \\
\hline
\end{tabular}

Source: Own elaboration.

\section{- Planning function}

The results of the web surveys reveal that, despite recent criticism, the budgeting process is still one of the most relevant management accounting devices. In 2013, it is used by $97.5 \%$ of the companies. This data is comparable to that in 2008 , where $96 \%$ of the firms declared to carry out a budgetary process.

It can be noticed, on one hand, from 2008 to 2013 the level of formalization of strategic planning has increased, but on the other hand, the link between the budget and the strategic plan has been strengthened. In $2013,77.5 \%$ of the companies declared to have quite formalized strategic planning, the percentage was $68 \%$ in 2008. Regarding the connection between the budget and strategic planning, it fully operates for $82 \%$ of the respondents in 2013 and for $75 \%$ of the companies in 2008 . This proves that companies understand better how the budgeting control system is involved with the process of strategic implementation.

The two surveys reveal that the companies have been improving their budgeting approach by re-engineering the process, bringing more automation, implementing software tools as ERP and using key performance indicators in a higher proportion (see Table 6).

Table 6

Tools already implemented to perform budgetary process

\begin{tabular}{c|c|c|}
\hline & $\mathbf{2 0 0 8}$ & $\mathbf{2 0 1 3}$ \\
\hline Process automation & $37,8 \%$ & $50,0 \%$ \\
\hline Use of an ERP system & $51,1 \%$ & $56,4 \%$ \\
\hline Use of KP & $60,0 \%$ & $71,8 \%$ \\
\hline Relative objectives (external references) & $33,3 \%$ & $43,6 \%$ \\
\hline Process reengineering & $11,1 \%$ & $25,6 \%$ \\
\hline Use of rolling forecasts & $35,6 \%$ & $38,5 \%$ \\
\hline Use of trend reports & $26,7 \%$ & $33,3 \%$ \\
\hline
\end{tabular}

ERP: Enterprise Resource Planning

KPI: Key Performance Indicator

Source: Own elaboration. 
The companies affirm that even if the environment is somewhat predictable, it is becoming more and more difficult to elaborate an accurate financial forecast (see Table 7). In $2013,83 \%$ of the respondents agree with the argument that in an uncertain environment, it is difficult to forecast precise and exact financial data. This result is much higher than the proportion of $69 \%$ encountered in 2008 at the beginning of the economic crisis. The 2013 web survey also reveals that $64 \%$ of the companies consider that once they have been approved, the budget figures become obsolete, the proportion was 52\% of companies considering their budget was quickly outdated in 2008 (see Table 7).

Table 7

Main findings from the web-based survey

\begin{tabular}{c|c|c}
\hline & 2008 & 2013 \\
\hline $\begin{array}{c}\text { The unpredictability of the environment doesn't allow to establish } \\
\text { accurate budgets }\end{array}$ & $69 \%$ & $83 \%$ \\
\hline $\begin{array}{c}\text { Once the budget is approved it becomes obsolete } \\
\text { Once the budget is approved, the objectives can be changed }\end{array}$ & $52 \%$ & $64 \%$ \\
\hline We obtain new resources to react to unexpected events & $54 \%$ & $65 \%$ \\
\hline
\end{tabular}

Source: Own elaboration.

These results offer striking similarities with a study published in Business Finance Research in 2009 where $28 \%$ of the surveyed companies affirm that their budget is outdated before the beginning of the forecasted financial year. Furthermore, $20 \%$ of the respondents believe that the budget is becoming obsolete during the first quarter and $19 \%$ during the first semester (Sweeney 2009).

However, in 2013, the web survey respondents mention that even if the environment is unstable and turbulent, the budget should be elaborated carefully, in order to establish direction and to detail action plans linked to the company strategy. The respondents developed the same argument in 2008 affirming that the budget can become obsolete at the level of detailed items, but the main financial targets remain reliable and companies should adapt their plans in order to cope with these high level objectives. Besides, they mentioned that the budget is not only a set of financial data but also a detailed action plan to reach a strategic objective.

\section{- Budget management function}

In order to soften the lack of accuracy of the forecasted financial indicators, the 2013 web survey reveals that companies are bringing more flexibility to their budgetary process. First of all, $72 \%$ of the companies report that they are systematically reviewing their actual figures in light of the budget target. In addition, the monthly budgetary review frequency has increased between 2008 and 2013 (see Table 8). In 2013, 40\% of the respondents proceed to a monthly review of their budgeted financial data, compared to $31 \%$ in 2008 . Furthermore, it is discerned a marked shift from quarterly review to monthly review. 


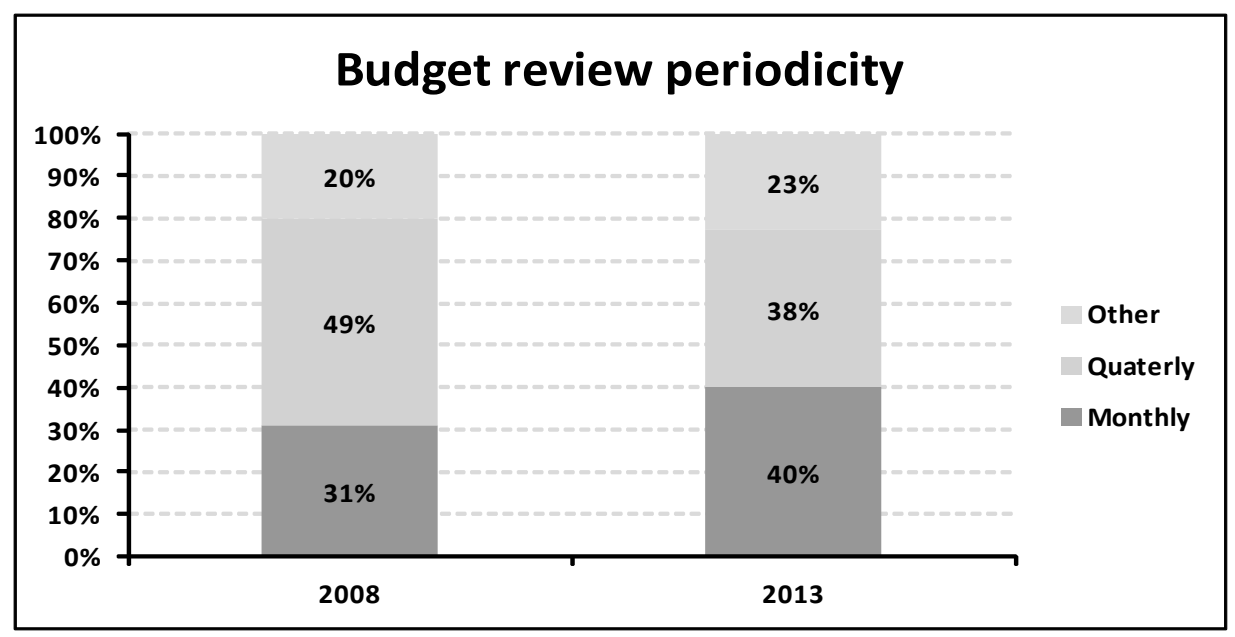

Budgetary review frequency

Source: Own elaboration.

Secondly, the surveyed companies outline that they have become more flexible when being allowed to make changes to the budget figures (see Table 7). The proportion of companies that are able to adjust their budget once it has been approved has increased considerably, from $44 \%$ in 2008 to $65 \%$ in 2013. Most of the respondents reveal that the implementation of Rolling Forecasts enables the company to continuously adapt the financial data, without losing sight on the strategic objectives that were defined during the planning stage.

The flexibility provided in the setting of objectives is reflected in the analysis of variances between actual results and budget at the end of the year. If variances above $10 \%$ are analysed, they reveal that, in $2008,41.7 \%$ of the companies reported variations of more than $10 \%$, versus $24 \%$ in 2013 . The percentage decreases in 2013 because companies can, to a greater extent, adjust their goals and adapt them to the current economic environment.

In 2013, the three most important factors causing variances are (see Table 9): an unexpected event, customer's actions and the poor prediction reliability. In 2008, the causes were identical, but respondents also highlighted the lack of environment information. Besides, it should be noted that, in 2013, the respondents underlined changes in laws and governmental regulations, such as major cause of variances. 
Table 9

Factors causing variances between actual data and budget

\begin{tabular}{c|c|c}
\hline & $\mathbf{2 0 0 8}$ & $\mathbf{2 0 1 3}$ \\
\hline Unexpected events & $64.6 \%$ & $53.7 \%$ \\
\hline Customers actions & $45.8 \%$ & $53.7 \%$ \\
\hline Poor prediction reliability & $35.4 \%$ & $46.3 \%$ \\
\hline Competitors actions & $33.3 \%$ & $39.0 \%$ \\
\hline Government actions & $20.8 \%$ & $34.1 \%$ \\
\hline Lack of environment information & $41.7 \%$ & $29.3 \%$ \\
\hline Weakness of action plans & $16.7 \%$ & $24.4 \%$ \\
\hline Employees actions & $8.3 \%$ & $19.5 \%$ \\
\hline Suppliers actions & $12.5 \%$ & $19.5 \%$ \\
\hline Technical problems & $18.8 \%$ & $14.6 \%$ \\
\hline Lack of target clarity & $18.8 \%$ & $12.2 \%$ \\
\hline
\end{tabular}

Source: Own elaboration.

In $2013,70 \%$ of the organizations have the possibility to obtain new resources outside the budgeting process, while only 54\% had this opportunity in 2008 (see Table 7).

In order to face the changes in the environment, companies are adapting their budgeting process in a more flexible way. The process is becoming more responsive to changes as $65 \%$ of the organizations have the possibility to modify their forecast once it has been approved and $70 \%$ have the opportunity to obtain new resources outside the budgeting process. Additionally, the survey reveals that the monitoring of the results is carried out more frequently by the companies; the budget is submitted to periodical reviews in $75 \%$ of the organizations and for $40 \%$ of them it is done on a monthly basis.

In 2013, following four years of an economic downturn, the relevance of the budgetary process is confirmed; planning and budgeting is still one of the central devices of management control. In addition, the difficulty to forecast in an uncertain environment is also confirmed. However, even if the financial figures are no longer accurate, the main strategic objectives remain for the target to be achieved. Finally, now companies review their budget more frequently and adopt mechanisms to improve their budgetary process, and make it more flexible.

\subsection{Qualitative interviews}

The case studies allows to address the second research question: Are companies bringing more adaptability to their budgeting process in order to cope with environmental uncertainty? If so, what are the main mechanisms that are implemented?

Several interviews were conducted to companies operating in different economic sectors, some classified as 'very unstable' and others 'quite stable' (see Table 10). To ensure 
the confidentiality of the data collected, the name of the companies visited has been replaced by a letter.

Table 10

\section{Interviewee Main Features}

\begin{tabular}{|c|c|c|c|c|c|}
\hline Company & $\begin{array}{l}\text { Economic } \\
\text { sector }\end{array}$ & $\begin{array}{c}\text { Sales } \\
(€ \text { Millions) }\end{array}$ & \# Employees & Environment & $\begin{array}{l}\text { Budget } \\
\text { review }\end{array}$ \\
\hline A & $\begin{array}{l}\text { Press (daily } \\
\text { newspaper) }\end{array}$ & $\begin{array}{c}239 \\
\text { (in 2011) } \\
\text { (-9\% vs. } \\
2010)\end{array}$ & $\begin{array}{c}488 \\
\text { (in 2011) } \\
\text { (-5\% vs. } \\
2010)\end{array}$ & $\begin{array}{l}\text { A leading player in } \\
\text { its sector, it operates } \\
\text { in a highly compe- } \\
\text { titive environment, } \\
\text { characterized by } \\
\text { rapid changes in } \\
\text { technology (printed } \\
\text { vs. digital) and a } \\
\text { high level of custo- } \\
\text { mer volatility. }\end{array}$ & $\begin{array}{c}\text { Monthly } \\
\text { review }\end{array}$ \\
\hline B & Retail & $\begin{array}{c}1.141 \\
\text { (in 2012) } \\
\text { (-28\% vs. } \\
2011)\end{array}$ & $\begin{array}{c}6.194 \\
\text { (in 2012) } \\
\text { (-19\% vs. } \\
2011)\end{array}$ & $\begin{array}{l}\text { A subsidiary of a } \\
\text { multinational orga- } \\
\text { nization. Leading } \\
\text { player in the Spanish } \\
\text { retail sector which } \\
\text { is characterized by } \\
\text { high competitive- } \\
\text { ness and a drop in } \\
\text { domestic spending } \\
\text { due to the VAT rate } \\
\text { and Personal Income } \\
\text { Taxes increases, } \\
\text { among other rea- } \\
\text { sons.To maintain } \\
\text { its competitiveness } \\
\text { company had to } \\
\text { reduce sales price. }\end{array}$ & $\begin{array}{l}\text { Review } \\
\text { every } 2 \\
\text { months }\end{array}$ \\
\hline $\mathrm{C}$ & $\begin{array}{l}\text { Consumer } \\
\text { goods }\end{array}$ & $\begin{array}{c}439 \\
\text { (in 2012) } \\
\text { (11\% vs. } \\
2011)\end{array}$ & $\begin{array}{c}1.589 \\
\text { (in 2012) }\end{array}$ & $\begin{array}{l}\text { A subsidiary of a } \\
\text { multinational or- } \\
\text { ganization. Quite un- } \\
\text { certain environment } \\
\text { - a leading player in } \\
\text { the consumer goods } \\
\text { sector, high price } \\
\text { sensitivity, high } \\
\text { level of consumer } \\
\text { volatility. }\end{array}$ & $\begin{array}{c}\text { Monthly } \\
\text { review }\end{array}$ \\
\hline
\end{tabular}




\begin{tabular}{|c|c|c|c|c|c|}
\hline $\mathrm{D}$ & Construction & $\begin{array}{c}160 \\
\text { (in 2012) }\end{array}$ & $\begin{array}{c}700 \\
\text { (in 2012) }\end{array}$ & $\begin{array}{l}\text { Quite stable but had } \\
\text { to support aggressi- } \\
\text { ve cuts in expen- } \\
\text { diture linked to a } \\
\text { lower demand of the } \\
\text { Ministry of Public } \\
\text { works. }\end{array}$ & $\begin{array}{l}\text { Quarter } \\
\text { review }\end{array}$ \\
\hline $\mathrm{E}$ & $\begin{array}{l}\text { Health } \\
\text {-Medical }\end{array}$ & $\begin{array}{c}2.724 \\
\text { (in } 2011) \\
(-12 \% \text { vs. } \\
2010)\end{array}$ & $\begin{array}{c}1.217 \\
\text { (in 2011) }\end{array}$ & $\begin{array}{l}\text { Stable - Foreseeable } \\
\text { future following the } \\
\text { life cycle of patented } \\
\text { products - Main } \\
\text { customer belonging } \\
\text { to the public sector. } \\
\text { Reduction of expen- } \\
\text { diture. }\end{array}$ & $\begin{array}{l}\text { Quarter } \\
\text { review }\end{array}$ \\
\hline
\end{tabular}

Source: Own elaboration.

The main objective of the in-depth interviews is to study the assumption that in a turbulent environment, the companies need more flexibility in their budgeting process to cope with uncertainties. Firstly, in order to analyze the need to balance the financial traditional budget with a higher degree of adaptability, its building process has been analysed for each company. Secondly, the study focuses on the way the main functions of business planning are interpreted and conducted in order to detect similarities and differences between the organizations, which could be the consequences of a turbulent environment.

The interviews reveal that the five companies have quite a similar planning process. The five companies employ the traditional budgeting approach and none of them uses the Rolling Forecasts ${ }^{3}$ technique for the following reasons:

- Lack of value added and high implementation costs when budget predictions are accurate (companies "E" and "D").

- Excessive workload (company “A”); and

- Possible confusion when considering manager's objectives (company “C”).

The main business functions listed by the interviewees are planning, budget management, as well as motivation. Other roles were also mentioned, such as organizational learning, communication and coordination. As these functions are less connected to the external environment, focus will be placed on the first ones.

\footnotetext{
${ }^{3}$ Rolling forecasts are financial projections that move in a mobile timeline in which progressively new periods are incorporated and older ones are deleted. The updated projections are reviewed quarterly and cover a period of four to eight quarters going beyond the fiscal year.
} 


\section{- Planning function}

Through the interviews it is shown that the companies operating in an uncertain environment ("A", "B" and "C") devote more time to the preparation and definition of their short term objectives and action plans.

The environmental uncertainty makes this phase absolutely essential. The organizations "A", "B" and "C" focus and spend time on defining different hypotheses for environmental factors, forecasting general economic context, analyzing trends in the markets, studying the intensity of the competition and anticipating changes in technologies and governmental regulations. Company "C" mentioned that they have to make a special effort to define as many scenarios as possible. They focus on threats analysis by systematically answering for every one of them "What if it happens?", "What if the general environment does not progress as initially forecasted?", "What if the new product or service to be launched doesn't meet expectations?", "What if we do not reach the expected advertising income?". In order to do so, they carry out several uncertainty analysis and financial simulations to study the risk impact on the company's activity and to come up with contingency plans, corrective actions and saving lists.

Company "A" also heavily insisted on the need to elaborate as many sensitivity analysis as possible. In addition, Company " $A$ " mentioned that the way of elaborating the budget has evolved since 2008; the managers are not any more challenged on the revenue target. Sales financial objectives are extremely difficult to reach due to the highly competitive environment and the drop of customers' purchasing power. Managers are now challenged on the cost structure. The dynamics of the budget have changed, the cost structure policy being extremely demanding. Managers should absolutely focus on cost savings, reduce fixed expenses as much as possible as well as the variable costs. The emphasis on cost control is a trend corroborated by the return of Zero Based Budgeting ${ }^{4}$ (ZBB). According to a study by the "Association Nationale des Directeurs Financiers et de Contrôle de Gestion" - "DFCG", in 2012, 25\% of the surveyed companies introduced the ZBB in their budgeting practices (Doche 2012).

For company "A" the way of considering the budget is now different: before, budget objectives were really demanding, but with the crisis stakeholders (shareholders, managers, employees) know that financial targets will not be easy to achieve and could be subject to some changes. However, the initial budget remains a reference which is maintained throughout the year.

Companies "D" and "E", which are operating in a more stable environment, declare that the planning process remains the same since the beginning of the crisis. Company E insisted on the fact that they only produce one budget; they don't work with different scenarios. However, Company " $D$ " insisted on the fact that - even if their environment is quite stable and easy to forecast - it is essential to validate the general assumptions that will guide the budgeting process.

\footnotetext{
4 The ZBB is a technique introduced in 1970 by Peter Pyhrr that systematically analyzes all costs budgeted, justifying each monetary unit of expenditure and prioritizing them based on a company's need. The ZBB is defined as: "a process that requires each manager to justify all their requests for funds. Each of them must demonstrate that expenditures proposed are really necessary. To perform that, the activities carried out in the organization should be carefully identified and assessed by means of a systematic analysis, to then sort them according to their importance" (Phyrr 1970).
} 
In summary, companies operating in an unstable environment try to imagine as many scenarios as possible so that business planning can enable the company to be responsive to changes in the business environment by previously identifying options for actions and improvement.

\section{- Management control function}

For all the interviewees, the budget is used as a reference to assess progress towards achieving the forecasted strategic objectives. They all conduct periodic reviews of the performance to analyze whether or not the company is on the right track to achieve its targets. Companies " $\mathrm{A}$ " and " $\mathrm{C}$ ", operating in an unstable environment, proceed to a monthly review and the Companies "D" and "E", working in a more stable environment, carry on a quarterly evaluation.

For Company "E" the control process is highly formalized and integrated. Reports are automated and issued on a regular basis. The information technology system includes signals in case of significant variance that alert managers, but usually there is almost no difference between the actual performance and the forecasted one. In this multinational company, lots of control mechanisms have been developed and implemented over the years and the management control system is a very mature one.

Regarding Company " $D$ ", the budgeting process is also integrated and automated and as the environment is quite stable (customers are mainly from public administration) there is nearly no relevant variance between actual and budget figures. Both Companies ("D" and "E") consider that the budget provides the right standard of reference for periodic monitoring and controlling process.

Company " $\mathrm{B}$ " is analyzing its actual results against its budget every two months. The results of these reviews are the basis for an update of the remaining revenues and costs. The retail performance is very sensitive to changes in revenues caused by the alterations in the economic environment or adjustments in laws and regulations. In 2012, the company registered a decrease of almost $28 \%$ in sales and a drop of $43 \%$ in the operating profit.

For that reason, the company is using a flexible budget in order to periodically adjust the operating costs to the level of income. The budget still remains the principal reference, but if the sales are below the objectives then the operating variable costs will be reduced by a higher percentage for the remaining period until the end of the fiscal year. Company "B" has implemented a hybrid planning model by using a flexible budget for variable costs (Ekholm and Wallin 2011). This hybrid model helps the organization to continually adapt its forecast to the changes in the environment without losing sight on the initial financial target.

Company "C" analyses actual results versus budget every month. The analysis of the causes of the variances helps to adjust action plans thanks to the contingency plans, corrective actions or saving lists previously defined in the phase of budget preparation. However, to avoid possible confusion, the initial budget remains unchanged. The budget stays the reference of comparison throughout the year.

For Company "A" the economic conditions have been extremely difficult; between 2007 and 2011 the income revenue decreased by 50\%. At the same time, the costs were 
reduced by the same percentage and the EBITDA $^{5}$ registered a decrease of almost $80 \%$. Regular reviews of the actual data are crucial to understand what is going on in the company. Every month is a new challenge and the question raised is "What will happen tomorrow?"

Since 2011, the budget is still the absolute global reference and the strategic objectives should be reached by any means. Nevertheless, the monthly reviews of actual figures are obtained comparing their evolution with respect to last year's indicators. In the context of uncertainty and worsening of the economic crisis, the budget figures quickly become obsolete at the detailed level and it would not make sense to use them as a standard of reference. The company " $A$ " believes that detailed historical indicators are the best reference for management control.

Regarding the analysis of Profit and Loss, the focus is now made on the costs, because the revenues are influenced by external factors and not completely controlled by the sales department. Indeed, the level of income depends on the newspaper's daily sales that are affected by the decrease of purchasing power and the emergence of new technologies. It is also due to advertising revenue that is subject to the decisions of advertisers who now commit themselves to the very short term (no more than three months). The company has to adapt itself to these circumstances and to direct its control on the level of fixed and variable costs and the amount of savings that had been achieved.

The regular monitoring of the progress of actual results is no longer carried out to detect variances with the budget, but to adjust the cost structure to the level of income in order to maintain a certain level of profitability.

To summarize, if the environment is stable, and if the budget is elaborated in good conditions, it is then considered as the best reference for management control. For companies operating in an uncertain environment, last year's reference is becoming the main quote to control the costs and to measure the actual performance.

\section{- Motivation function}

For the interviewees, the budget is the reference for the incentive policy and should not be changed even if the economic context is adverse. Furthermore, the budget represents an operational manager's commitment to achieve an objective he has formulated and which has been negotiated and approved by his hierarchy. For all the respondents, performance evaluation and incentive rewards are based on actual performance measured against budget. If the budget objective is not reached then the incentive will be reduced in a similar proportion.

Given the current economic context, the financial objectives will be difficult to reach; in order to maintain motivation levels the incentive schemes could include individual objectives (such as safety in the workplace, employee professional development, innovation, etc.) and collective objectives concerning the company's overall performance benchmarked with direct competitors.

\footnotetext{
${ }^{5}$ EBITDA: Earning before interest, taxes, depreciation and amortization.
} 


\section{CONCLUSIONS}

The web survey and the interviews reveal that, even though Spanish respondent companies are facing greater market uncertainties, budgeting remains essential and more than $97 \%$ of them are still using it. Budgeting is viewed as a fundamental component of the management control system. The main planning functions, anticipation, regulation and motivation enhance managers' capacities to anticipate and effectively manage strategic uncertainties and provide a way of controlling that the company is on track with the preset objectives.

Investigation results reveal that, to cope with the evolution of the environment, budgetary practices, among the studied companies, are oriented towards greater flexibility and adaptability of the process. The survey shows that in 2013, it appears to be more difficult to establish reliable predictions than in 2008. As a matter of fact, $83 \%$ of the companies think that the unpredictability of the environment doesn't allow them to establish accurate figures (versus $69 \%$ in 2008). Furthermore $64 \%$ of the respondents believe that once the budget is approved it becomes obsolete.

In addition, between 2008 and 2013, the empirical investigation reveals that the organizations are adapting their budgeting process. Firstly, the process has been reengineered and more than $55 \%$ of the respondents use an ERP system in 2013. Secondly, the frequency of the budgetary reviews has increased, and $40 \%$ of the organizations are now carrying out monthly reviews which constitute a platform for ongoing monitoring of performance and action plans. Finally, companies are able - in a much higher proportion - to modify their budget objectives once they have been approved (65\% in 2013 versus $44 \%$ in 2013).

Within the mechanisms that companies adopt to get the most of the budgeting process are a greater care in the preparation of the budget and a deeper analysis of the costs variances, placing greater emphasis on their evolution over the previous year. Regarding the budgeting process itself, it is observed that with the recession the companies are working harder on forecast preparation, multiplying the scenarios and systematically adopting a "What if?" approach. The priority is to understand what is driving the future performance, to identify as many risks and opportunities as possible in order to prepare contingency plans and to foresee a re-allocation of resources, if necessary. The overall building process should, in the end, ensure the achievement of the organization's general strategic objectives.

Besides, the companies operating in a quite uncertain environment are monitoring the costs and the resources employed in their processes very closely. They estimate that the revenue figures are too difficult to control and the only way to achieve the budgeted target is by focusing attention on the cost structure. The best method to monitor the costs, in an adverse environment, is not to compare them to the budget, but to analyze their evolution with regard to last year. Another way mentioned by the companies is to use a flexible budget for variable costs which are then automatically linked and adjusted to the level of revenue.

Finally, companies consider that the budgeting process enhances managers' commitment and motivation by orienting their behavior and decisions toward achieving the organization's objectives. 
In light of the results, it can be argued that depending on the stability of the environment, companies are adapting, or not, their budgeting practices. Companies operating in a stable environment do not feel the need to modify their initial process, whereas organizations confronted with the turbulent environment need to adjust their action plans to achieve the present objectives and adapt the monitoring of their performance focusing on the cost structure. Moreover, the interview analysis suggests that in a fast moving environment, as is the case in Spain, the budgeting process is crucial for the organizations if costs are to be controlled and forecasted results are to be achieved.

The results of the empirical investigation suggest that the budgeting process is still an imperative for the organizations, and that in an uncertain environment, it provides a set of references and milestones that can serve as a stable framework.

The organizations should be able to progress at the same pace by constantly adapting their plans to the external context. The flexibility brought by the possibility to modify targets, to obtain additional resources outside the planning procedure or to use flexible budgets, helps the budgeting process to be more closely linked to the real word.

In summary, the investigation suggests that the budgeting process is deeply rooted in the organizations. Companies maintain their forecast procedures because it brings them value even if environmental uncertainty increases.

One of the limits of the present study is that the findings rely on a small number of respondents and interviewed organizations. Nevertheless the sample size has been the same for the two web-surveys conducted in 2008 and 2013 and relies on the consistency and the comparability of the results obtained.

\section{REFERENCES}

Amat, J.M., Soldevila, P. and Castelló, G., 2002. Control presupuestario. $2^{\mathrm{a}}$ ed. Barcelona: Gestión 2000.

Apanaschik, G., 2007. 2007 Budgeting and Forecasting Study. PwC Advisory, Performance improvement, 1-45.

Arwidi, O. and Jönsson, P., 2009. Management control practices in Sweden - discussion and positioning of survey results. EIASM, 5th conference on performance measurement and management control, Niza.

Barret, E. and Fraser, L.B., 1977. Conflicting roles in budgeting for operations. Harvard Business Review, Julio-Agosto, 137-146.

Baudet, R., 1941. Les fonctions du budget. In: N. Berland (2004). Mesurer et piloter la performance. Paris: Editions La Performance, 96-97.

Berland, N., 1999. A quoi sert le contrôle budgétaire? Les rôles du budget. Finance, Contrôle, Stratégie, 2 (3), 5-24.

Berland,N.,Levant,Y.and Joannides, V.,2009.Institutionalization anddeinstitutionalization of budget. Symmetrical analysis of rhetoric associated to the introduction of budget and Beyond Budgeting. 30ème congrés Association Francaise de Comptabilité (AFC). Strasbourg.

Bouquin, H., 2001. Le contrôle de gestion. 5ème ed. Paris: PUF. 
Bunce, P., Fraser, R. and Woodcok, L., 1995. Advanced budgeting: a journey to advanced management system. Management Accounting Research, 6, 253-265.

Courtney, H., 2008. A fresh look at strategy under uncertainty: An interview. The McKinsey Quarterly, December, 1-8.

Covaleski, M.A., Evans, J.H. III, Luft, J.L. and Schields, M.D., 2003. Budgeting research: Three theorical perspectives and criteria for selective integration. Journal of Management Accounting Research, 15, 3-49.

Doche, F., 2012. Observatoire International du Contrôle de Gestion - Résultats 2012. Les cahiers Techniques, DFCG, 7.

Duncan, R., 1972. Characteristics of organizational environments and perceived environmental uncertainty. Administrative Science Quarterly, 17 (3), 313-327.

Ekholm, B. and Wallin, J., 2011. The Impact of Uncertainty and Strategy on the Perceived Usefulness of Fixed and Flexible Budgets. Journal of Business Finance and Accounting, 38 (1) and (2), January-March, 145-164.

Fernández, A. and Rodríguez, E., 2011. Itinerario histórico y situación actual de la disciplina presupuestaria empresarial. De Computis, Revista Española de Historia de la Contabilidad, 14, Junio, 50-78.

Frow, N., Margisson, D. and Odgen, S., 2010. Continuous budgeting: Reconciling flexibility with budgetary control. Accounting, Organizations and Society, 35, 444-461.

Hofstede, G., 1977. Contrôle budgétaire: les règles du jeu. Paris: Editions Hommes et Techniques.

Hope, J. and Fraser, R., 1997. Beyond budgeting... Breaking through the barrier to the third wave. Management Accounting, 75, 11, 20-23.

Hope, J. and Fraser, R., 2000. Beyond budgeting. Strategic Finance, 82 (4), 30-35.

Hope, J. and Fraser, R., 2003. Who needs budgets? Harvard Business Review, 81 (2), 108115.

Hopwood, A.G., 1974. Leadership climate and the use of accounting data in performance evaluation. The Accounting Review, 49, 485-495.

Horngren, C.T., Sundem, G.L. and Stratton, W.O., 1996. Introduction to Management Accounting, Nueva York: Prentice Hall.

Hunt, S., 2006. Building finance performance management mastery with superior budgeting and forecasting capabilities. Accenture, Finance and Performance Management, 1-11.

International Monetary Fund, 2013. World Economic Outlook Database. Abril 2013. Washington: IMF.

Jensen, M.C., 2001. Corporate budgeting is broken - let's fix it. Harvard Business Review, 79 (10), 94-101.

Libby, T. and Lindsay, M., 2010. Beyond budgeting or budgeting reconsidered? A survey of North-American budgeting practice. Management Accounting Research, 21, 56-75.

Lorain, M.A., 2010. Should rolling forecasts replace budgets in uncertain environments? In: Epstein, M.J., Manzoni, J-F and Dávila, A., eds. Performance Measurement and Management Control: Innovative Concepts and Practices, vol. 20. Esmerald Books, 177-208.

Lyne, S.R., 1988. The role of budget in medium and large U.K. companies and the relation with budget pressure and participation. Accounting and Business Research, 18 (71), 195-212. 
Merchant, K.A., 1998. Modern management control systems - text and cases. New Jersey: Prentice Hall Inc.

Neely, A., Bourne, M. and Heyns, H., 2001. Driving value through strategic planning and budgeting. A Research Report from Cranfield School of Management and Accenture. Accenture, Finance and Performance Management, 1-47.

Otley, D.T., 1977. Behavioural Aspects of Budgeting. Accountant's digest, 49, 1-32.

Otley, D.T., 2006. Trends in budgetary control and responsibility accounting. In: Bhimani, A., ed. Contemporary Issues in Management Accounting. Oxford: Oxford University Press, 291-307.

Phyrr, P., 1970. Zero based budgeting. Harvard Business Review, 48 (6), 111-121.

Ryan B., Scapens R. and Theobald M., 2004. Metodología de la investigación en Finanzas y Contabilidad. Barcelona: Ediciones Deusto.

Samuelson, L.A., 1986. Discrepancies between the roles of budgeting. Accounting, Organizations and Society, 11 (1), 35-45.

Santesmases Mestres, M., 2009. DYANE Versión 4 - Diseño y análisis de encuestas en investigación social y de mercados. Madrid: Ed. Pirámide.

Simons, R.S., 1995. Levers of Control. Boston: Harvard Business School Press.

Sweeney, J., 2009. The budget (1922-2009). Business Finance, May-June, 12-17.

Van der Stede, W.A., 2000. The relationship between two consequences of budgetary controls, budgetary slack creation and managerial short term orientation. Accounting, Organizations and Society, 25 (6), 609-622. 


\section{APPENDIX}

Surveyed questions about environment uncertainty and budgetary process.

Q1 - What type of financial management tool do you use in your company?

Response: Yes or No

- Financial Accounting

- Analytical Accountancy

- Cost Analysis

- Balanced Scorecard

- Annual Budgeting

- Strategic Planning (2 to 5 years)

- Rolling Forecasts

- Analysis of variances

Q2 - Define how you perceive your environment:

Scale:

- 1 (Very stable)

- 2 (Somewhat stable),

- 3 (Stable)

- 4 (Somewhat unstable)

- 5 (Very unstable)

Please specify why do you think so.

Q3 - How difficult is to predict the following factors:

Scale: 1 (highly predictable), 2 (somewhat predictable), 3 (predictable), 4 (somewhat unpredictable), 5 (highly unpredictable)

- Changes in customer demand

- Evolution of customer preferences

- Changes in product offered by competitors

- Technical developments impacting design

- Technical developments impacting production

- Governmental changes to laws and regulations

- Actions of labor unions

- Availability of suitable employees

- Availability of raw materials

- Price of raw materials

Q4 - Please specify if you agree with the following assessments:

Scale: 1 (strongly disagree), 2 (somewhat disagree), 3 (agree), 4 (highly agree), 5 (strongly agree)

- "The unpredictability of the environment doesn't allow to establish accurate budgets".

- "Once the budget is approved it becomes obsolete".

Q5. - Please specify why do you think so. 
Q6 - Define the level of formalization of your budget and strategic planning

Scale: 1 (highly formalized), 2 (somewhat formalized), 3 (not very formalized), 4 (not formalized at all).

- Strategic planning

- Budget

Q7 - When do you establish your action plans?

- Before the annual budget

- After the annual budget

- We don't have any formalized action-plan.

Q8 - The budgetary process is closely linked to the strategic planning:

- Always

- Never

- In some occasion

Q9 - Do you reached your strategic planning in the past two years?

- Always

- Never

- In some occasion

Q10 - During the last year the variance between actual results and budget was:

Scale: $1(0-5 \%), 2(5-10 \%), 3(10-20 \%), 4(20-30 \%), 5(+30 \%)$

- Total budget

- Sales budget

- Costs of goods sold

- Administrative and general expenses

Q11 - The factors causing variances between actual and budget are:

Scale: 1 (very little importance), 2 (little importance), 3 (average importance), 4 (high importance), 5 (extreme importance)

- Lack of target clarity

- Weakness of action plans

- Poor prediction reliability

- Lack of environment information

- Unexpected events

- Technical problems

- Employees actions

- Customers actions

- Competitors actions

- Suppliers actions

- Government actions

Q12 - If variances are caused by other factors, please list them below: 
Q13 - In your company:

Response: Yes or No

- "Once the budget is approved, the objectives cannot be changed".

Q14 - In your company:

Response: Yes or No

- "If it is not in the budget, we cannot obtain new resources to react to unexpected events".

Q15 - The frequency of the budgetary reviews is:

- Monthly

- Quaterly

- Twice a year

- Never

- Other, please specify:

Q16 - In your opinion, the most relevant management accounting tools are:

Scale: 1 (strongly agree), 2 (agree), 3 (desagree).

- Activity-Based budgeting

- Rolling Forecast

- Balanced Scorecard

- Relative aspirational goals

- Beyond Budgeting

Q17 - What changes to your budgetary process do you intend to implement?

Scale: 1 (No we do not intend to do it), 2 (We already have implemented it), 3 (Not yet, but we are thinking about it), 4 (Yes we intend to do it in the next to years)

- Process automatization

- Use of an ERP system

- Use of Key Performance Indicators

- Changes in the workflow information, for instance bottom-up

- Relative objectives with external references (market, competitors)

- Reengineer the process to gain time in the elaboration

- Use of Rolling Forecasts

- Use of trends reports

Q18 - Please specify if you intend to implement some other modification to your budgetary process:

Questions Q19 to Q23: were related to description of survey respondent characteristics: Corporate structure, Number of employees, Divisional revenues, Economic sector and Respondent's Job title. 
